\title{
DETERMINANTS OF LABOR DEMAND IN COLOMBIA: $1976-1996$
}

\author{
Mauricio Cárdenas and Raquel Bernal \\ CID Working Paper No. 72 \\ June 2001
}
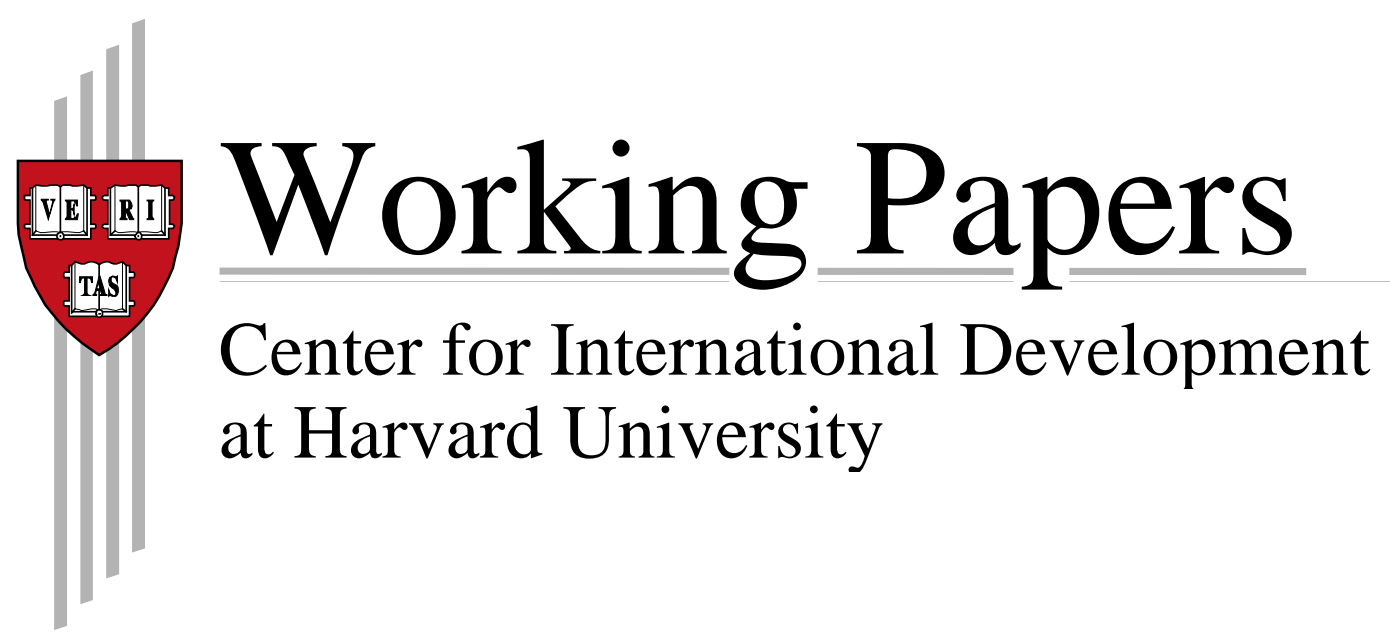



\title{
DETERMinants OF LABOR DEMAND IN COLOMBIA: $1976-1996$
}

\author{
Mauricio Cárdenas and Raquel Bernal
}

\section{INTRODUCTION}

In spite of a labor reform introduced in 1990, as part of a reform package that liberalized the economy in many dimensions, Colombia's unemployment rate is now over 20\%. The 1990 reform made labor contracts more flexible, including a reduction in job security provisions. The most significant change took place in relation to severance payments with the introduction of a system of individual accounts managed by specialized private funds. Under the old system, employers managed the funds and employees were allowed to make partial withdrawals at any time. These withdrawals were debited in nominal terms at the time of separation, adding to the costs faced by employers. In practice, the new system implied a reduction in the level and uncertainty of severance payments for firms. In fact, the initial effect of the reform was to lower non-wage labor costs to $42.9 \%$ of the basic wage, from $47.1 \%$ during the late 1980 s. However, the reform did not deal with other important areas of labor legislation, especially payroll taxation 2

The reform package also included a Social Security law, enacted in 1993, which raised employers' mandatory contributions for health and pension programs. From the viewpoint of the labor market, this reform had important implications resulting from the significant increase in non-wage labor costs. In fact, by 1996 non-wage labor costs had risen to $52 \%$ of the basic salary, an increase of nearly 10 percentage points relative to their level in 1991.

\footnotetext{
${ }^{1}$ This paper was mostly written while the authors were affiliated with Fedesarrollo in Bogotá, Colombia. We are grateful to Daniel Hamermesh, Carmen Pagés and Juan Mauricio Ramírez for comments and suggestions, and to Jairo Augusto Núñez for his valuable help in processing the data for this project.
} 
This paper analyzes the combined effect of these two reforms on labor demand ${ }^{\text {B }}$. The results indicate that the increase in labor costs resulting from the pension and health reform had a negative impact on labor demand. Thus, the paper calls for a new generation of labor market reform in Colombia, aimed at reducing non-wage labor costs.

The paper is structured in the following way. Section 2 discusses the institutional and regulatory framework governing the labor market, with special attention to the changes introduced in the 1990 and 1993 reforms. Special emphasis is placed on measuring the non-wage costs implied by the regulation. Section 3 shows the main stylized facts in the labor market during the 1976-1996 period. Section 4 deals with the incidence of payroll taxation on wages in a framework analyzes that tests for the possible endogeneity of wage and non-wage labor costs. More specifically, the section tests whether higher non-wage costs faced by employers have been transferred to workers in the form of lower basic wages. The results suggest that firms do not lower wages when facing higher non-wage labor costs resulting from the legislation. The paper then moves to the analysis of labor demand. Section 5 estimates standard labor demand equations with the time series data. The emphasis of the estimation is placed on the measurement of the own-wage elasticities, as well as the elasticities of substitution between different factors of production. It also tests for possible changes in the value of those elasticities, associated with the reform package of the early 1990s ${ }^{7}$ Section 6 presents the results of estimating the determinants of labor demand in a dynamic framework that considers explicitly the impact of the regulations

\footnotetext{
${ }^{2}$ The reform kept a 9\% payroll tax earmarked for labor training by SENA (2\%), social welfare programs for the unprotected childhood by ICBF (3\%), and family subsidies provided by the privately managed Cajas de Compensación $(4 \%)$.

${ }^{3}$ Kugler (in this volume) analyzes the effects of changes in job security provisions, such as severance payments and other dismissal costs, on labor turnover.

${ }^{4}$ Trade liberalization was an essential part of the package. As is well known, trade liberalization can make labor demand more elastic by making output markets more competitive and by making domestic labor more substitutable with foreign factors. Or in the words of Hicks (1964, p. 242), "the demand for anything ids likely to be more elastic, the more elastic is demand for any further thing which it contributes to produce".
} 
on the path of employment adjustment. Section 7 presents the results of labor demand estimations based on a panel of manufacturing sectors.

The main conclusion of the paper is that labor demand elasticities in Colombia are around -0.5 , a value that is not low (in absolute terms) by international standards. Ceteris paribus, the increase in labor costs has resulted in a significant reduction in labor demand. The message is that the payoff, in terms of greater employment, of a reduction in payroll taxes is considerable. Given the current levels of unemployment it is high priority to undertake such an initiative.

\section{LABOR LEGISLATION: RECENT CHANGES}

As mentioned in the introduction, the regulation of the labor market in Colombia saw important changes during the 1990s. This section summarizes key aspects of the 1990 labor reform and the reform to the social security system that was enacted in $1993 \square$

- Severance pay was the highest non-wage labor cost under the pre-1990 regime. Employees were entitled to one-month salary per year of work (based on the last salary). Partial withdrawals were allowed and deducted in nominal terms from the final payment, implying a form of "double retroactivity" (with an estimated cost of $4.2 \%$ of the total wage bill) $\frac{6}{6}$ The new legislation eliminated this extra cost in all new labor contracts and introduced a monthly contribution (9.3\% of the basic salary) to a capitalized fund in the workers' name accessible in the event of separation or retirement. Thus, the reform effectively reduced the level of severance payments. It also eliminated the employers' uncertainty about the cost of severance payments.

- The reform increased the indemnity paid to workers dismissed without "just cause". Workers with less than a year of tenure on the job receive 45 days' wages. Workers with more than one year of tenure receive 45 days for the first year plus an additional amount for each extra year.

\footnotetext{
${ }^{5}$ See Lora and Henao (1995), Cárdenas and Gutiérrez (1996), Lora and Pagés (1997), and Guash (1997).
} 
This implies an increase relative to the old regime. For example, in the event of separation, a worker with more than 10 years of tenure on the job used to receive 30 days for each extra year (after the first). As can be seen in Table A1, the new legislation increased the indemnity to the equivalent of 40 days' wages per additional year. Although the legal definition of "just cause" was widened, the reform increased the costs of dismissal.

- However, the right of workers with more than 10 years tenure to sue for reinstatement was eliminated. Prior to the reform, successful plaintiffs could oblige firms to rehire workers with back pay.

- Workers earning more than 10 minimum wages were allowed to opt for a new contract ("integral salaries") with higher wages instead of severance pay and other mandatory benefits (such as the especial bonus or 'prima'). However, in a survey conducted by Fedesarrollo in 1994, manufacturing firms reported that less than $2 \%$ of the employees had this type of contract.

- Labor contracts for less than one year were allowed (renewable up to three times under the same terms 8 , provided that all benefits are paid in proportion to the duration of the contract.

- Legal restrictions on the creation of labor unions were lifted. In particular, the Ministry of Labor lost discretionary powers in this regard. Also, it became unlawful for employers to discourage the creation of labor unions. A minimum of 25 workers is still necessary to form a union.

- The 1993 social security and health reform (Law 100) increased total contributions for health from $7 \%$ of the basic salary (until 1994) to $8 \%$ in 1995 and $12 \%$ afterwards. One-third of the total contribution has to be paid by the employer (same proportion as in the old system).

\footnotetext{
${ }^{6}$ Apart from tenure, the real cost of termination of employment increased with the frequency of partial withdrawals, uncertain to the employer.

${ }^{7}$ Based on the highest salary during the last year of employment.

${ }^{8}$ The fourth renovation has to be made for at least one year. See Farné and Nupia (1996).
} 
- The same law increased pension contributions to $13.5 \%$ in 1996 (14.5\% for workers that earn more than four minimum wages) from $8 \%$ of the basic salary in 1993. The increase was implemented gradually. Contributions were first raised to 11.5\% in April 1994 and then to $12.5 \%$ in 1995 . Employers currently pay 10.1 percentage points of the total contribution, as opposed 4.3 before the reform ${ }^{2}$.

Table 1 and Figure 1 summarize the effects of labor and social security reform on nonwage labor costs. For workers with contracts signed prior to 1990 , the total non-wage labor cost paid by the firm (as a percentage of the basic salary) raised from $47.1 \%$ in 1990 to $56.2 \%$ in 1996 (and thereafter). For workers with contracts signed after 1990, employers now pay 52\% of the basic salary in contributions. In exchange for higher salaries, these contributions are substantially lower (33.8\%) in the case of employees hired under the "integral salary" contract.

For the purpose of the analysis, we divide non-wage costs into three relatively arbitrary categories: First, “deferred wages" which include vacations, extra bonuses, pension and health contributions. In theory, deferred wages affect the total labor cost but do not have an impact on the path of employment adjustment. Second, severance payments, which in addition to the direct

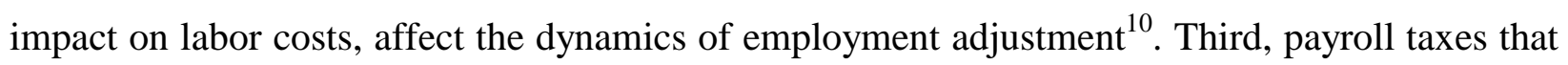
fund programs with benefits that cannot be fully internalized by the employee (e.g., ICBF, SENA, and Cajas) ${ }^{1}$. The economic response to these three types of non-wage costs may be different. In the case of deferred wages the employee can offset part of the cost by adjusting the wage. This may not be the case of payroll taxes earmarked for the provision of public goods. In the fourth section we analyze the possible effect of deferred wages on current wages by

\footnotetext{
${ }^{9}$ Law 100 (1993) eliminated the monopoly of the Social Security Institute (ISS) in the provision of health and pensions. The coverage of health services was extended to the whole family and to low-income groups that were unattended under the previous system. In relation to the pension system, employees were given the option of choosing between the old pay-as-you-go system or the new fully funded system provided by private pension funds.

${ }^{10}$ Strictly speaking, severance payments are also deferred wages.
} 
estimating a Mincer-type income equation. The hypothesis is that the employer may transfer non-wage costs to workers through lower wages.

The upper panel of Figure 1 shows the evolution of severance payments, as well as health and pension contributions for an average worker as percentage of the basic wage between 1976 and $1996 \sqrt{12}$. The middle panel shows the evolution of payroll taxes. These taxes increased by one percentage point in 1982 (earmarked to SENA) and again by an equal amount in 1989 (earmarked for $I C B F$ ). Vacations and extra bonuses have remained constant throughout the period. The bottom panel adds all these costs together. The cumulative effect shows an increasing trend until 1990. After the 1990 labor reform, non-wage labor costs fell as a result of the changes introduced to the legislation related to severance payments. However, since 1994 these costs have increased sharply as a result of the 1993 health and pension reforms.

\section{STYLIZED FACTS}

Figure 2 displays the unemployment rate for the period 1976-1998. After reaching a peak in March 1986 (14.6\%), unemployment rates declined steadily until 1994 when they were under 8\%. Unemployment rates have increased sharply since 1995. The figure for September 2000 $(20.5 \%)$ is the highest in the modern Colombian economic history. Although much of the explanation of greater unemployment is related to significant increases in labor supply, this paper argues that labor demand cannot be ignored. In fact, the increase in the cost of labor -combined with a relatively high own wage elasticity- had a negative impact on labor demand. However, this is not the only explanation. The 1990 labor reform has also caused greater employment

\footnotetext{
${ }^{11}$ Of course, if the linkage between payroll taxes is weak or if the external benefits of social security programs are significant, then partial or complete finance by general revenues may be appropriate. See Kesselman (1995).

${ }^{12}$ Workers under "integral salaries" are excluded. After 1991 we ignore workers under pre-1990 contractual terms.
} 
volatility in response to economy-wide shocks. This has been the result of greater flexibility in the creation and destruction of jobs. Kugler (in this volume) addresses this issue in detail.

This paper uses mainly data on output, employment (skilled and unskilled) and wages for Colombia's seven largest cities. These variables are available for seven sectors: (1) manufacturing, (2) electricity and gas, (3) construction, (4) retail, restaurants and hotels, (5) transportation and communications, (6) financial services, and (7) personal and government services. The data come from the quarterly National Household Survey (NHS), which has been conducted uninterruptedly since 1976. Output data come from the quarterly GDP series processed by DNP.

\section{Employment and Production}

Table 2 displays some basic descriptive statistics on urban employment for the period 1976-1996. Manufacturing and personal and governmental services provide $29 \%$ and $25 \%$ of the urban jobs, respectively. We use information only for wage earners, which account for $64 \%$ of the total urban workers (62\% before the 1990 labor reform). However, there are sharp differences across sectors. In manufacturing, $76 \%$ of the workers earn a monetary wage, while in retail and restaurants only $50 \%$ of the workers do.

We use a measure of skill that includes high school graduates plus all of those with some tertiary education (all workers with 12 or more years of schooling). By using this definition, the group of more educated workers represented $23 \%$ of urban employment on average between 1992 and 1996. According to Figure 3, this group's share in total urban employment has increased steadily since 1976, reflecting the greater educational attainment of the population. Indeed, average years of schooling have increased continuously during the past two decades. As 
can be seen in Table 2, skilled workers represent more than $30 \%$ of total employment in public utilities, financial services, and personal and government services. These shares have increased significantly since 1992 .

Figure 4 describes the evolution of employment and production in the Colombian urban sector. It is interesting to note that after 1991 skilled employment has grown faster than unskilled employment is most sectors. This has been particularly true in the case of manufacturing, where employment of unskilled workers has fallen in absolute terms since 1993. The same trend is observed in the construction sector after 1994. These two sectors combined employ approximately $35 \%$ of the unskilled wage earners in the urban regions.

\section{Factor Prices}

Information about labor income received by wage earners (skilled and unskilled) comes from the National Household Survey. Given that this is not necessarily equal to the total labor cost paid by the employer (which is the relevant price in the estimation of labor demand) it is then necessary to quantify non-wage labor costs and construct a measure of the total labor cost. We do that by using the information contained in Figure 1, which summarizes all non-wage labor costs, expressed as a percentage of the basic salary. This includes severance payments, payroll taxes, and contributions for health and pensions on the part of the employer.

It is not entirely clear whether income reported by the individuals surveyed in the NHS includes benefits such as vacations, mandatory bonuses and severance payments. Nonetheless, it is probably safe to assume that individuals report their basic pre-tax salary, without benefits. In order to obtain the total labor cost we add all the non-wage labor costs measured in Figure 1 to the basic salary reported in the NHS. Implicitly, this means assuming the independence of wage 
and non-wage costs. We do this based on the results of the next section, which support the idea that employees do not transfer higher non-wage costs imposed by the legislation through lower basic salaries. Finally, the overall cost is then deflated using the Producers Price Index. The procedure is identical for skilled and unskilled workers $\frac{13}{13}$. For completeness, we also report the user cost of capital measured according to a standard methodology described in Cárdenas y Gutiérrez (1996) $\frac{14}{14}$

Figure 5 shows the evolution of real factor costs by sector. There are three key insights for the 1990s: First, the cost of labor increased significantly; second, the cost of labor has increased faster than the cost of capital; third, the cost of skilled relative to unskilled labor rose during this period. In fact, the user cost of capital decreased considerably during the period 19921994 as a result of the reduction in the interest rate and the real currency appreciation. As shown in Table 3 the average annual growth in real labor costs between 1992 and 1996 was $11.4 \%$ for skilled workers and $8.4 \%$ for unskilled workers. These rates are substantially higher than the average for the pre-reform period. In sum, labor costs increased in an unprecedented way after 1990, especially in the case of skilled workers.

\section{Endogeneity of Wage and Non-wage Costs.}

As mentioned above, we need to support our assumption that wage and non-wage costs can be added together ignoring the incidence of payroll taxation on wages. Several authors have warned against this assumption, arguing that wages and non-wage costs are endogenously

\footnotetext{
${ }^{13}$ As mentioned in Section 2, workers with high remuneration (over 10 minimum wages) under 'integral salaries' contracts have much lower non-wage costs (33.8\% of the basic salary vs. $52 \%$ in contracts with full benefits). However, the NHS survey does not provide information on the contract type so we assume that all workers are paid full benefits. This is probably a correct assumption due to the fact that less than $2 \%$ of workers in manufacturing had this type of contract in 1994 (according to a survey conducted by Fedesarrollo).

${ }^{14}$ Our measure of the user cost of capital is higher than the one obtained by Pombo (1997), who estimates the depreciation rates (and the corresponding tax deductions) for different asset types in the manufacturing sector.
} 
determined. This is the case of Newell and Symons (1987) for the European context and in Gruber (1995) for Chile. Their view is that ignoring this issue can be misleading when making policy recommendations.

There are different ways to deal with this potential endogeneity. Some authors estimate an equation of the wage rate as a function of the payroll tax rate and a constant. If the coefficient on the payroll tax rate variable is equal to -1 , then they conclude that taxes are fully shifted into wages. This is the procedure used by Gruber (1995).

Here we adopt a somewhat different procedure. We estimate the determinants of wages based on information from the National Household Surveys. Every two years (in June) the NHS includes a special module on informality where workers report whether they are covered by the social security system. We use the data from the June 1988, 1992 and 1996 surveys (including the special module) to estimate a Mincer-type income equation. The regressions are based on data for each one of the surveyed workers and allow us to understand whether an individual's wage, given certain personal characteristics, is negatively affected when the individual contributes to the social security system ${ }^{5}$.

Our assumption is that if employers transfer the non-wage labor cost to employees, then workers that are registered in the social security system would have lower wages (after controlling for other personal characteristics that may affect wages) than those that are not

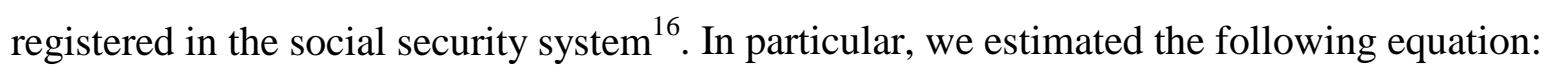

$$
\ln w_{t}=\beta_{o}+\sum_{i} \beta_{i} p e r s+\beta_{5} d u m s s+\beta_{6} m w+\beta_{7} d u m s s * m w+\sum_{i} \beta_{i} \sec +\sum_{i} \beta_{i} c i t y+\varepsilon_{t}
$$

where pers is a vector of personal characteristics that include average years of schooling, gender, and experience; dumss is a dummy variable which takes a unitary value when the individual is

\footnotetext{
${ }^{15}$ The percentage of workers with health coverage rose to $60 \%$ in 1996 from 50\% in 1988 .
} 
registered in the social security system (i.e. the employer pays social security contributions); $m w$ is a dummy variable that controls for individuals that earn the minimum wage ${ }^{17}$ (payroll taxes cannot be transferred to these workers in the form of lower wages); sec is a vector of dummy variables that account for 9 economic sectors and city is a vector of dummy variables for each of the seven main cities.

Table 4 presents the results of estimating equation (1). The adjustment of the regression is high (R-squares are around 0.55) given the total number of observations (approximately 25.000 depending on the year). The personal characteristics variables appear with the correct sign and are statistically significant. In particular, returns to education are positive (but low) and the coefficient is highly significant. The positive coefficient of the dummy variable for gender indicates that given other personal characteristics, labor income is relatively higher for men. In turn, experience has a positive but decreasing impact on wages. The dummy variables that account for the economic sectors and the city of location also come out significant.

Turning to the variables of interest for this exercise, for a given set of personal characteristics, workers covered by the social security system have higher wages than uncovered workers. This is of interest because it indicates that employers do not transfer social security contributions to workers in the form of lower wages. According to the sign of the coefficient, individuals that earn the minimum wage have lower incomes than what would be predicted by their personal characteristics. This is less true in the case of workers that earn the minimum wage and that are registered in the social security system.

In sum, the evidence suggests that payroll contributions do not have a negative impact on wages. Therefore, the results of this section provide the necessary support in order to use our

\footnotetext{
${ }^{16}$ Ribero and Meza (1997) and Sánchez and Núñez (1998) have estimated Mincer-type income equations for Colombia.

${ }^{17}$ For the purpose of this exercise, the minimum wage in 1988 was $\$ 28.000$, in $1992 \$ 72.000$ and in $1996 \$ 155.000$.
} 
measure total labor costs, which is simply the sum of wage and non-wage costs. We now turn to the estimation of the labor demand equations.

\section{STATIC LABOR DEMAND}

The purpose of this section is to measure the own wage elasticities of the demand for labor, as well as the elasticities of substitution between different factors of production $\frac{18}{\text { The }}$ literature is rich in terms of functional forms that can be used for the estimation. If changes in the elasticity of substitution are of interest, the Generalized Leontief (GL) function is a common choice. The GL specification is also normally used when information is available for more than two factors of production 19

The derived factor demands from a GL cost function (see Appendix 1) can be written as:

$$
\frac{x_{i t}}{y_{t}}=\sum_{j} b_{i j}\left(\frac{p_{j t}}{p_{i t}}\right)^{\frac{1}{2}}+\alpha_{i} y_{t}+\gamma_{i} t
$$

where $x_{i t}$ is the quantity of factor $i$ used in period $t, y_{t}$ is output in period $t, p_{i t}$ is the price of input $i$ in period $t$, and $t$ is a time trend. Changes in the input-output ratio can be the result of: (a) changes in relative factor prices; (b) changes in the scale of production (if the production function is not homothetic); and (c) technological change. Diewert (1971) has shown that the GL cost function corresponds to a fixed coefficients technology (no factor substitution) if $b_{i j}=0$ for all $i \neq j$. Also, the production function exhibits constant returns to scale if $\alpha_{i}=0$ for all $i$ (i.e., the function is homothetic). Clearly, factor-augmenting technological change does not occur if $\gamma_{i}=0$

\footnotetext{
${ }^{18}$ Defined as the effect of a change in relative factor prices on relative input use of the two factors, holding output and other factor prices constant.

${ }^{19}$ See Hamermesh (1986).
} 
for all $i$. Based on the estimated $b_{i j}$, s, we then calculate the own wage elasticity for factor $i\left(\eta_{i i}\right)$ as:

$$
\eta_{i j}=-\frac{y \sum_{j \neq i} b_{i j}\left(p_{j} / p_{i}\right)^{1 / 2}}{2 x_{i}} .
$$

In turn, the Hicks-Allen partial elasticities of substitution between input $\mathrm{i}$ and input $\mathrm{j}\left(\sigma_{\mathrm{ij}}=\sigma_{\mathrm{ji}}\right)$ can be easily calculated. The appropriate expressions in the case of the GL technology are $\left(s_{j}\right.$ is the cost share of input $\mathrm{j}$ ):

$$
\sigma_{i j}=\frac{\frac{y}{2 x_{i}} b_{i j}\left(\frac{p_{j}}{p_{i}}\right)^{\frac{1}{2}}}{s_{j}},
$$

for all $i \neq j$. In this case, the elasticity of substitution is not constant across time. In fact, as can be observed in equation (4), its value depends on the inputs quantities and prices. Finally, the elasticity of input $i$ with respect to output is given by:

$$
\varepsilon_{i}=1+\frac{\alpha_{i} y^{2}}{x_{i}}
$$

Thus, when the technology exhibits constant returns to scale the output elasticity is equal to one.

\section{ReSUlts}

This section summarizes the main results of the estimation of static labor demand equations with quarterly data from the urban Household Surveys. The estimation is carried out first with data for the manufacturing sector alone, based on a system of two equations for the demand of skilled and unskilled labor. The equations use the number of hours worked as the 
dependent variable. We then turn to the data for the seven largest metropolitan cities, using a similar framework but dropping capital as a factor of production.

\section{MANUfACTURING}

Table 5 presents the results on the factor demands for skilled and unskilled labor. According to the GL specification, the system of two equations describing the behavior of the input-output ratios was estimated using a (Gauss) Full Information Maximum Likelihood Procedure (FIML). In order to correct for first order serial autocorrelation of the error the lagged residuals were added to each equation (AR1).

The system was estimated with and without the symmetry restrictions $\left(b_{i j}=b_{j i}\right)$. Conveniently, Theil has shown that minus twice the log of the likelihood ratio (i.e. maximum of the likelihood function imposing symmetry over the maximum of the likelihood function in the unconstrained case) has a Chi-square $\left(\Pi^{2}\right)$ distribution (with degrees of freedom equal to the number of restrictions imposed $)^{20}$. The test rejected the null hypothesis of symmetry. Also, in the estimations the coefficient $\gamma_{i}$ came out not significantly different from zero rejecting the hypothesis of factor-augmenting technological progress.

The estimated $b_{i j}$ 's (excluding the trend term from the equations) are significantly different from zero, rejecting the existence of a fixed proportion technology (a Leontief production function). Importantly, the signs of the coefficients indicate that the two types of labor are substitutes. The hypothesis of constant returns to scale is also rejected at high levels of significance. The estimated $\alpha_{i}$ coefficients are all positive and significant. This implies that both

\footnotetext{
${ }^{20}$ See López (1980).
} 
employment/output ratios increase as the scale of production is expanded (i.e. the production function is non-homothetic).

Based on the estimated $b_{i j}$ 's we then compute the relevant elasticities that, according to the formulae, are time dependent. We report the elasticities for three periods: 1980-1985, 19861991, and 1992-1996. The two types of labor show a decreasing degree of substitutability. Own wage elasticities are negative. For the $1992-1996$ period their value is around -0.35 for skilled workers and -0.4 for unskilled workers. This means that a $10 \%$ reduction in wages is related to a 3.5-percent increase in the demand skilled and 4-percent increase in the demand for unskilled

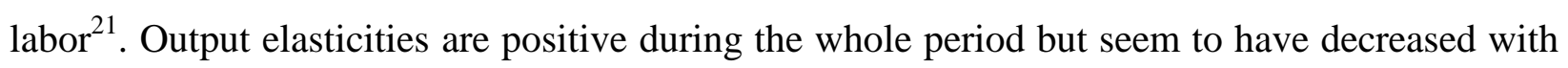
time. In particular a 1-percent increase in production is related to a $2 \%$ increase in skilled labor demand and a 1-percent increase in unskilled labor demand. 2 .

\section{SEVEn Metropolitan AREaS}

Table 6 shows the results of the estimation in the case of the demand for hours worked by skilled and unskilled labor (without capital) in the seven largest metropolitan areas. Besides changes in relative prices, we added a demand shifter in the equation. In particular we introduced the investment rate for the urban economy into equation (2), in order to assess any possible changes in labor demand holding constant relative prices.

Again, the Wald test rejected the null hypothesis so we estimated the $b_{i j}$ 's without symmetry restrictions. The coefficients turned out significantly different from zero, rejecting the existence of a fixed proportion technology. The estimated ${ }_{i}$ coefficient for skilled employment

\footnotetext{
${ }^{21}$ The results using a CES function are somewhat different. In this case, a $10 \%$ decrease in wages is related to a $0.8 \%$ increase in skilled labor demand and a $1.7 \%$ increase in unskilled labor demand respectively. Again, the two types of labor show increasing substitutability, just as in the case of capital and unskilled labor. On the other hand skilled labor and capital are complements. These results are available upon request.
} 
is positive and significant. This implies that skilled employment/output ratio increases as the scale of production is expanded (i.e. the production function is non-homothetic). Based on the estimated $b_{i j}{ }^{\prime} s$ we computed the relevant elasticities. The two types of labor show a decreasing degree of substitutability as can be seen in Figure 6. On average, the elasticity of substitution between skilled and unskilled employment was 0.93 between 1976 and 1996.

Own-wage elasticities are higher in this case than in the manufacturing sector. In particular, a $10 \%$ decrease in wages is related to a $4.5 \%$ increase in skilled labor demand and a $5.1 \%$ increase in unskilled labor demand. In the case of unskilled labor, the own-wage elasticity has increased in absolute value during the post-reform period to 0.51 from 0.46 in the pre-reform period. On the other hand, output elasticities are positive. A one-percent increase in output is related to a $1,8 \%$ increase in skilled labor demand and a one-percent increase in unskilled labor demand. Higher investment rates increase both skilled and unskilled labor demand. Yet, this effect has been slightly higher in the case of skilled employment.

Finally, we estimated equation (1) adding a dummy for the post reform period (alone and interacted with the relative prices). The coefficients on these variables did not tun out significant. This means that the effects of the reforms are already captured in the changes in relative prices or in the demand shifter that was added to the equation. The results (not reported) on these regressions are available upon request.

\section{DYNAMIC LABOR DEMAND}

The existence of adjustment costs of changing employment (net changes) and changes in firing and hiring (gross changes) implies that firms do not adjust instantly to changes in the

\footnotetext{
${ }^{22}$ The results when splitting up into two subsamples (after and before the reform) are statistically insignificant.
} 
variables mentioned in the previous section. To capture this issue, we estimated a dynamic labor demand equation that is derived in Appendix 2:

$$
n_{t}=c+\alpha_{0} y_{t}+\alpha_{1} y_{t-1}+\beta_{0}\left[w_{t}+n w_{t}\right]+\beta_{1}\left[w_{t-1}+n w_{t-1}\right]+\gamma_{t} n_{t-1}+u_{t}
$$

where $n$ is employment, $y$ is a rolling autoregression forecast of production, $w$ is a rolling autoregression forecast of basic wages, $n w$ are non-wage labor costs that do not affect the path of employment adjustment, and $u$ is an error term. Non-wage labor costs include vacations, bonuses, health and pension contributions and payroll taxes (all added as \% of basic wage). In turn, ${ }_{t}$ is a measure of the costs of adjustment, which depends on the regulations that affect the path of employment. Following Burgess and Dolado (1989) we interact different types of regulation with $n_{t-1}$. In particular, we assume that:

$$
\gamma_{t}=\gamma_{0}+\gamma_{1} R 1_{t}+\gamma_{2} R 2_{t}
$$

where $R l$ denotes severance payments (expressed as a percentage of the basic salary) and $R 2$ denotes dismissal costs (indemnity for dismissal without just cause expressed in terms of the number of monthly wages for workers with 10 or more years in the firm ${ }^{2}$ ). As mentioned in Section 2, severance payments fell as a result of the 1990 labor reform, while the indemnity for unjust dismissal increased 24 . These two changes in the regulation should have had opposite effects on the costs of adjustment. The reduction in severance payments should have reduced the costs of adjustment (a reduction in ${ }_{t}$ ), while the increase in dismissal costs should have worked in the opposite direction. Importantly, the 1993 pension and health reform increased labor costs but should not have affected the costs of adjustment.

\footnotetext{
${ }^{23}$ This variable is taken as a proxy for dismissal costs for all workers. Although desirable, we were unable to redefine the dependent variable in order to measure employment of workers with 10 or more years in their current job only.

${ }^{24}$ However, the elimination of the right to sue for reinstatement with back pay should have reduced the expected firing costs.
} 
This formulation is useful in order to assess the impact of a one-unit increase in the costs of regulations on the level of employment (the $\beta$ 's) and that of this increase in the cost per worker on the path of employment adjustment (the $\gamma$ 's). In the former case, we can infer the impact or short-run multiplier coefficient $\left(\beta_{0}\right)$ and the long or equilibrium multiplier $\left(\beta_{0}+\beta_{1}\right)$. Moreover, we can test whether these multipliers changed as a result of the structural reforms. This can be done as a quasi-natural experiment by including a post-reform dummy interacted with wages and the lagged employment measure.

\subsection{Econometric Results}

Table 7 presents the results of the estimation of equation (7) with quarterly data from the household surveys. In order to avoid potential endogeneity in the shocking variables, we used rolling-regression (i.e. continuously updated) forecasts of the product demand and wages instead of their actual values. In the case of output, the forecast is based on fourth order autoregression. Wages are forecasted with a third order autoregression.

The first three columns show the results of estimating (7) for total urban employment. Unfortunately, we cannot include R1 and R2 in the same regression due to collinearity of the variables. The results are of interest. The first three columns indicate that the product elasticity of employment is 0.57 , while the wage elasticity is zero in the short run (impact) but -0.16 in the long run. The results also suggest that the changes in the regulations did not have an impact on adjustment costs. In fact, the coefficient on lagged employment indicates that quarterly changes in employment are on average only $40 \%$ of the desired adjustment, irrespective of the changes in the regulation. 
The remaining regressions separate skilled and unskilled employment. The results suggest that output and price (in absolute value) elasticities are larger for skilled workers. The costs of adjustment were not affected by changes in the regulations regarding severance payments and dismissal costs for either type of worker. Moreover, when a post-reform dummy was interacted with the wage variables the estimated coefficient did not come out significant. This result gives support to the point made in the previous section, suggesting that structural reform did not affect the price elasticity of labor demand. In this sense, structural reforms did have an impact on labor demand through its effect on relative prices alone $e^{5.5}$.

In sum, the results of this section suggest that regulations add to static labor costs rather than to the dynamics of employment adjustment. Therefore, in the next two sections we will revisit the static labor demand estimations, using micro data. Before we move in that direction we present the results of some simulation exercises based on the dynamic labor demand estimation. The simulations are illustrative of the effects of different changes that could be introduced to labor legislation.

\subsection{Simulations}

In this section, we perform a simulation exercise in order to assess how changes in payroll taxes and labor costs affected employment growth in Colombia. For this purpose, we used equations (3), (4) and (5) in Table 8 to estimate what would have happened to employment had health and pensions contributions not been increased during the 1993 labor reform.

Figure 7 shows the fitted value of employment according to the dynamic labor demand specifications presented in Table 7. Panel A shows the results in terms of total employment, while panel B and C report unskilled and skilled employment, respectively. As employment is in

\footnotetext{
${ }^{25}$ Slaughter (1997) has found that labor demand has been growing less elastic over time in the U.S.
} 
logs, the difference between the two lines represents the percentage change. According to this information also presented in Table A2, during the last quarter of 1996 total employment would have been 1.3\% higher if health and pensions contributions had not changed during 1993. Similarly, unskilled employment would have been $1.85 \%$ higher and skilled employment $2.2 \%$ higher.

Figure 8 depicts the results of a similar exercise. In this case we simulate what would have occurred if the 9\% payroll tax had been eliminated in 1993. In this case, employment would have been $1.3 \%$ higher during the last quarter of 1996, compared to what actually happened. The figures for unskilled and skilled employment are $1.8 \%$ and $0.9 \%$, respectively.

\section{Labor Demand in a Panel of Manufacturing Establishments}

This section presents some results of the estimation of a homogeneous labor demand equation with a balanced panel of Colombian manufacturing firms. The panel was obtained from the Annual Manufacturing Survey (MAS) and includes 2570 firms throughout the period 19781991. The total labor cost was obtained directly for the surveys by adding wages and other benefits (prestaciones). In the specification of the model we follow Bentolila and Saint Paul (1992). In particular, we estimate:

$$
n_{i t}=\alpha_{0}+\alpha_{1} n_{i, t-1}+\alpha_{2} w_{i t}+\alpha_{3} p_{i t}+\alpha_{4} k_{i t}+\alpha_{5} d y_{i t}+\alpha_{6} t+\varepsilon_{i t}
$$

where $n_{i t}$ is the $\log$ total employment by firm $i$ at time $t, w_{i t}$ is the log of wage paid by the firm (including benefits) deflated by the producers' price index, $p_{i t}$ is the $\log$ of the price of intermediate goods consumed by the firm (also deflated by the producers' price index), $k_{i t}$ is the 
$\log$ of stock of capital, $d y_{i t}$ is the growth rate in gross production by the firm, and $t$ is a time trend.

The results are reported in Table 8. The first and second columns show the results of the estimation with least squares and instrumental variables, respectively. In the latter, we use the lagged values of employment and intermediate goods' prices as instruments (both at time $t$-2), as well as the contemporaneous growth rate in government consumption and the stock of capital. The results confirm the negative but low value (in absolute terms) of the short-run wage elasticity of labor demand in the manufacturing sector (around -0.05). However, the long-run value of this elasticity is substantially higher in absolute terms (-2.27). The long-run elasticity with respect to other inputs' prices is positive (1.36), suggesting labor and intermediate goods are substitutes in production.

Growth in gross output seems to have a statistically significant effect on employment. Indeed, the results of the estimation indicate that a one-percentage point increase in the rate of output growth results in a 0,24-percentage growth in employment. This result is in line with the time series evidence of the previous section. In order to correct heteroskedasticity problems we controlled for fixed effects by adding 28 sectorial dummy variables to the equation. The results remained virtually unchanged.

Finally, we interacted the list of regressors with a dummy variable that captures differential responses to the business cycle. The dummy variable takes a unitary value when output growth for the firm is over $4 \%$ and zero when growth is below $2 \%$. If the growth rate is between $2 \%$ and $4 \%$, the assigned value at time $t$ depends on growth at $t-1$.

The results suggest that the wage elasticity of labor demand decreases (in absolute terms) during expansions, while the elasticity with respect to the price of intermediate inputs increases. 
Thus, an increase in the cost of intermediate goods induces greater substitutability vis-à-vis labor during expansions than during recessions. Lagged employment shows the expected result, lower inertia in expansion, and the coefficient is highly significant. Lastly, the results suggest an asymmetric labor demand response to the business cycle conditions. The impact of output growth on employment is larger during recessions than during expansions.

In sum, labor demand elasticities derived from establishment data are lower (in absolute value) than the ones obtained with aggregate data for the manufacturing sector. This is true both in the case of own wage and output elasticities. The results of this section also indicate that the demand for labor is more elastic in downturns than during expansions. This could explain why unemployment rates rise very rapidly but take a long time to fall, a pattern that has been found in Colombia.

\section{Labor Demand in a Panel of 92 Manufacturing Sectors}

This section estimates equation (8) using data from 92 industrial sectors (corresponding to the 4-digit CIIU classification) from 1978 to 1995 . In this case, the log of value added replaces the growth rate in gross production. The results are presented in Table 9 were all the variables are in logs. The first column presents the basic equation estimated by ordinary least squares. The second column corrects fixed effects and the third column uses instrumental variables, where lagged values of employment, intermediate goods' prices (both at time $t$-2) and the stock of capital (at time $t-1$ ) as well as the contemporaneous values of the stock of capital and wages are the instruments.

The estimated real wage elasticity is higher (-0.6) in absolute terms than the value estimated with the firm-level data. Using IV the long-run wage elasticity is -1.43 . The elasticity 
with respect to input prices is on average -1.2 depending on the method of estimation. Contrary to the firm-level results, the negative sign suggests that labor and intermediate goods are complements in production. Value added has a positive and statistically significant effect on employment. According to these results, a one-percent increase in value added results in a 0.45 percentage growth in employment.

Finally, the last three columns in Table 9 show the results when the basic equation is interacted with a dummy variable equal to 1 from 1992 to 1995 (and 0 otherwise) in order to assess for possible changes in the coefficients after the implementation of structural reform. The coefficient on lagged employment indicates that employment has been more flexible since 1992 (lower inertia).

On the other hand, the elasticity with respect to total wage seems to have decreased (in absolute value) after 1991. Similarly, the response of employment to changes in value added virtually disappeared during the post-reform period. The elasticity with respect to material prices turns out to be positive during the post-reform period, indicating that labor and intermediate goods are substitutes in production. Interestingly, the positive response of employment to the capital stock increased significantly after the new labor regulation was implemented.

\section{Conclusions}

This paper has analyzed the determinants of the demand for labor in Colombia's urban sector (seven largest metropolitan areas) using different sources of data. The main focus of the paper is to estimate the own-wage elasticities of labor demand in order to quantify the effects of payroll taxation on employment generation. This is a critical area for policy design, given the abnormal levels of unemployment that the country is facing. 
Some have argued that the relevant elasticities are low, discouraging policymakers from undertaking major reforms. The common belief is that the efficiency gains associated with labor reform are relatively weak while the political costs of changing current labor legislation are very high. This paper argues that, quite on the contrary, the payoff of reducing labor costs is substantial.

In order to reach that conclusion, the paper analyses the impact of recent changes in the costs of employment and measures their impact on labor demand. The estimated wage elasticities are summarized in Table 10. Using the more reliable quarterly time series obtained from the National Household Surveys these elasticities range from -0.45 to -0.52 , depending on the type of labor. However, when the elasticities fall (in absolute terms) when the estimation uses a dynamic framework. In this case, the long run own-wage elasticity is -0.16 .

In the case of the manufacturing sector the elasticities are somewhat lower. Using the time series data they range between $-0,35$ (skilled) and -0.40 (unskilled). In a panel of 91 manufacturing sectors the estimated value is -0.6 (in the short run) and -1.43 (in the long run). These results change dramatically in a regression that uses establishment data. In this case the short run elasticity is only -0.05 , although its long-run counterpart is -2.27 .

Output elasticities are larger. In the static labor demand framework the estimates are close to 2 for skilled workers and 1 for unskilled labor. In the dynamic specification they are 1 for skilled and 0.6 for unskilled employment. Again, the elasticities fall when panel data is used.

The paper also analyses the impact of changes in the regulations on adjustment costs. The conclusion is that changes in severance payments and costs of dismissal, associated with the 1990 labor reform, did not affect the path of employment adjustment. Using this framework, we also conclude that structural reforms did not change the relevant elasticities. This means that the 
main effect of regulatory changes affected labor demand though their direct impact on labor costs. Since these costs have increased it is likely that the net effect of labor, health and pension reforms has been a reduction in employment generation. According to the estimated elasticities in the dynamic framework, an elimination of the $9 \%$ payroll taxes could result in a 1,3\% increase in employment in the urban areas. Of course, the impact is much greater when the elasticities derived from the static exercise are used. In this case, a 10\% reduction in labor costs could result in a $5 \%$ increase in labor demand.

Using a panel of manufacturing establishments we also concluded that the wage elasticity of labor demand increases (in absolute terms) during contractions. The impact of output growth on employment is also larger during recessions than during expansions. In this sense, we found an asymmetric labor demand response to the business cycle conditions. Lastly, we did not find evidence of a significant effect of structural reforms (i.e. trade liberalization) on the relevant labor demand elasticities. We conclude that the effects of reforms on labor demand were the result of changes in relative prices alone.

\section{REFERENCES}

Bentolila, S., and G. Saint-Paul (1992) "The Macroeconomic Impact of Flexible Labor Contracts, with an Application to Spain", European Economic Review, Vol. 36, 10131053.

Bernal, Raquel, M. Cárdenas, J. Núñez, and F. Sánchez (1997) "Macroeconomic Performance and Inequality in Colombia: 1976-1996" Fedesarrollo, Working Papers Series, Number 1.

Blanchflower, D. and A. Oswald (1994). The Wage Curve. Cambridge: MIT Press.

Burda, M. (1991) "Monopolistic Competition, Costs of Adjustment, and the Behavior of European Manufacturing Employment", European Economic Review, Vol 35, pp. 61-79. 
Burgess, S. and Juan Dolado (1989) "Intertemporal Rules with Variable Speed of Adjustment: An Application to U.K. Manufacturing Employment", The Economic Journal (June), pp. 347-365.

Cárdenas, M. and Olivera, M. (1995) "La Crítica de Lucas y la Inversión en Colombia: Nueva evidencia," Ensayos sobre Política Económica, June.

, Andrés Escobar and Catalina Gutiérrez (1995a) "La Contribución del Infraestructura a la Actividad Económica en Colombia, Ensayos Sobre Política Económica, December, 1995.

, Andrés Escobar and Catalina Gutiérrez (1995b) "Productividad y Competitividad en Colombia: 1950-1994" mimeo, Fedesarrollo.

and Catalina Gutiérrez, (1996) "Impacto de las reformas estructurales sobre la eficiencia y la equidad: la experiencia colombiana en los noventa", en Coyuntura Económica, XXVI, 4, December.

Diewert, W. E. (1971) "An Application of Shephard Duality Theorem: A Generalized Leontief Production Function," Journal of Political Economy, 79, 481-507.

Gonzaga, Gustavo (1997) "The Effects of Openness on Industrial Employment in Brazil" in M. Cárdenas (Editor) Empleo y Distribución del Ingreso en América Latina: ¿Hemos avanzado?, forthcoming.

Gruber, Jonathan (1995) "The Incidence of Payroll Taxation: Evidence from Chile", Working Paper Series No. 5053, National Bureau of Economic Research, Cambridge, March.

Farné, Stefano y Oskar A. Nupia (1996) "Reforma Laboral, Empleo e Ingresos de los Trabajadores Temporales en Colombia", Coyuntura Social, No. 15, Bogotá, Noviembre.

Guash, J. Luis (1997) "Labor Reform and Job Creation: The Unfinished Agenda in Latin American and Caribbean Countries", mimeo, The World Bank, Washington, April.

Hamermesh, D. S. (1986) "The Demand for Labor in the Long-Run", in Handbook of Labor Economics, eds. O. Ashenfelter and R. Layard, Vol. 1. North Holland.

, (1993) Labor Demand, Princeton: Princeton, NJ.

and Gerard A. Pfann (1996) "Turnover and the Dynamics of Labour Demand", Economica, Vol. 63, No. 251, pp. 359-367, August.

Hicks, John R. (1963) The Theory of Wages, New York: St. Martin’s Press.

Kesselman, Jonathan R. (1995) “A Public Finance Perspective on Payroll Taxes", mimeo, Department of Economics, University of British Columbia, Vancouver, December. 
Kugler, Adriana D. and Mauricio Cárdenas (1998) "The Effects of Firing Costs on Turnover: The Colombian Labor Market Reform as a Natural Experiment", mimeo, Fedesarrollo.

Lancaster, Tony (1990) The Econometric Analysis of Transitional Data, Econometric Society Monographs, 17, Cambridge University Press.

Layard, Richard, Nickel S., y Jackman R (1994) "Unemplyment. Macroeconomic Performance and the Labour Market", Oxford University Press.

Lora, Eduardo and Martha L. Henao (1995) "Efectos Económicos y Sociales de la Legislación Laboral”, Coyuntura Social, No. 13, Bogotá, Noviembre.

Lora, Eduardo y Carmen Pagés (1997) "La Legislación Laboral en el Proceso de Reformas Estructurales de América Latina y el Caribe", in M. Cárdenas (Editor) Empleo y Distribución del Ingreso en América Latina: ¿Hemos avanzado?, forthcoming.

Newell, A. and Symons, J. S. V. (1987) "Corporatism, Laissez-faire, and the Rise in Unemployment” European-Economic-Review; 31(3), April, pages 567-601.

Nickell, Steve (1986) "Dynamic Models of Labor Demand", Chapter 9, Handbook of Labor Economics, Vol. II, pp. 473-522.

Ocampo, José Antonio (1987) "El regimen prestacional del sector privado" in J. A. Ocampo and Manuel Ramírez (eds.) El Probelam Laboral Colombiano, Informe de la Misión Chenery, Contraloría General de la República-DNP.

Pombo, Carlos (1997) "How high is the user cost of capital for the Colombian industrial entrepreneur?" mimeo, University of Illinois.

Ribero, Rocío and Claudia Meza (1997) "Ingresos laborales de hombres y mujeres en Colombia: 1976-1995", Archivos de Macroeconomía, documento \# 62. Departamento Nacional de Planeación.

Sánchez, Fabio and Jairo Núñez (1998) "La Curva de Salarios para Colombia. Una Estimación de las Relaciones entre el Desempleo, la Inflación y los Ingresos Laborales, 1984-1996", Archivos de Macroeconomía, documento \# 80. Departamento Nacional de Planeación.

Schaffner, Julie A. (1996) "Urban Job Stability in Developing Countries: Evidence from Colombia", mimeo, Department of Economics, Stanford University, October.

Slaughter, Matthew J. (1997) "International Trade and Labor-Demand Elasticities" NBER working paper \# 6262. 


\section{Appendix 1. Generalized Leontief (GL) Cost Function}

The GL cost function can be written as:

$$
C(P, Q, t)=Q \sum_{i} \sum_{j} b_{i j} p_{i}^{1 / 2} p_{j}^{1 / 2}+Q^{2} \sum_{i} \alpha_{i} p_{i}+Q t \sum_{i} \gamma_{i} p_{i}
$$

where $\mathrm{Q}$ denotes output and $p_{i}$ is the price of input $\mathrm{i}(t$ is time). The function is homogeneous of degree one in prices and does not impose symmetry, concavity or homotheticity. Assuming price-taking behavior in factor prices and using Shephard's Lemma one can derive costminimizing input demand functions:

$$
X_{i}=\frac{\partial C}{\partial P_{i}}=\sum_{j} b_{i j}\left[p_{j} / p_{i}\right]^{1 / 2} Q+\alpha_{i} Q^{2}+\gamma_{i} Q t
$$

where $X_{i}$ is the quantity demanded of input $i$. Factor demands can be expressed in terms of inputoutput ratios:

$$
\frac{X_{t i}}{Q_{t}}=\sum_{j} b_{i j}\left[p_{j t} / p_{i t}\right]^{1 / 2}+\alpha_{i} Q_{t}+\gamma_{i} t+\mu_{i t}
$$

\section{Appendix 2. Analytical Framework for the Dynamic Labor Demand Estimations} A Cobb-Douglas production function can be written as:

$$
Y_{t}=A N_{t}^{\alpha} K_{t}^{(1-\alpha)}
$$

where $A$ denotes a technological parameter, $L$ the level of total employment, $K$ the capital stock and $\alpha$ the proportion of employment in production.

First order conditions can be written as:

$$
W_{t}=\frac{\delta Y_{t}}{\delta N_{t}}=\alpha A N_{t}^{* \alpha-1} K_{t}^{1-\alpha}
$$

Expressing equation (A5) in logarithms:

$$
\ln W_{t}=\ln \alpha A-(1-\alpha) \ln N_{t}^{*}+(1-\alpha) \ln K_{t}
$$

Rearranging terms:

$$
\ln W_{t}=\ln Y_{t}+\ln \alpha A+\ln A+\alpha \ln N_{t}^{*}-(1-\alpha) \ln N_{t}
$$

If lowercase letters denote logs, then (A7) is equivalent to:

$$
\begin{aligned}
& n_{t}^{*}=\frac{c+y_{t}+w_{t}}{(1-\alpha)} \\
& n_{t}^{*}=c+\alpha y_{t}+\beta w_{t}
\end{aligned}
$$


An adjustment equation satisfies:

(A10)

$$
n_{t}-n_{t-1}=(1-\lambda)\left(n_{t}^{*}-n_{t-1}\right)+\varepsilon_{t-1}
$$

Rearranging terms:

$$
n_{t}^{*}=\frac{n_{t}-n_{t-1}}{(1-\lambda)}+n_{t-1}-\frac{\varepsilon_{t-1}}{(1-\lambda)}
$$

Substituting (A9) into (A11):

$$
\frac{n_{t}-n_{t-1}}{(1-\lambda)}+n_{t-1}-\frac{\varepsilon_{t}}{(1-\lambda)}=c+\alpha y_{t}+\beta w_{t}
$$

Rearranging terms:

$$
n_{t}=(1-\lambda) c+\alpha(1-\lambda) y_{t}+(1-\lambda) \beta w_{t}+\lambda n_{t-1}+\varepsilon_{t}
$$

We now suppose firms have rational expectations and $n_{t}^{e}$ satisfying the following condition:

$$
n_{t}^{e}=(1-\lambda) n_{t}+\lambda n_{t-1}^{e}
$$

where superscript $e$ denotes expectations. Substituting recursively for $e_{t-s}^{e}$, we can obtain:

$$
n_{t}^{e}=\frac{(1-\lambda)}{(1-\lambda L)} n_{t}
$$

where $\mathrm{L}$ is the lag operator. Then (A13) can be rewritten as:

(A16)

$$
n_{t}=(1-\lambda) c+\alpha y_{t}-\alpha \lambda y_{t-1}+\beta w_{t}-\lambda \beta w_{t-1}+\lambda n_{t-1}-\lambda^{2} n_{t-2}+\varepsilon_{t}-\lambda \varepsilon_{t-1}
$$

which is the estimated equation. 
NON WAGE COSTS

(as \% of basic wage)

\begin{tabular}{ccccc}
\multicolumn{2}{c}{ Contracts before 1990 } & & \multicolumn{2}{c}{ New Contracts } \\
\cline { 1 - 1 } \cline { 4 - 5 } in 1990 & after 1990 & & $\begin{array}{l}\text { with full } \\
\text { benefits }\end{array}$ & $\begin{array}{c}\text { integral } \\
\text { salary }\end{array}$ \\
\hline
\end{tabular}

\section{Severance Payments}

Nominal rate

$9.3 \quad 9.3$

4.2

9.3
4.2

Double Retroactivity

\section{Other benefits}

Vacations (15 days a year)

$\begin{array}{llll}6.7 & 6.7 & 6.7 & 6.7 \\ 8.9 & 8.9 & 8.9 & \ldots\end{array}$

\section{Social Security Contributions}

Pensions

$6.5 \quad 13.5$

(paid by the worker)

(2.2)

Health

7

(paid by the worker)

12

13.5

(3.4)

12

14.5

(2.3)

(4.0)

(4.0)

(4.4)

12

\section{Payroll Taxes}

$\begin{array}{ll}9.0 & 9.0\end{array}$

9.0

9.0

SENA

2.0

2.0

2.0

2.0

3.0

3.0

3.0

3.0

Cajas de Compensación

4.0

4.0

4.0

4.0

Total

$51.6 \quad 63.6$

59.4

42.2

Total paid by firm

47.1

56.2

52.0

33.8

Total paid by worker

4.5

7.4

7.4

8.4

Memo: shares in total employment in 1994

manufacturing

commerce

\begin{tabular}{llcl} 
na & 20.7 & 53.6 & 1.5 \\
na & 14.5 & 71 & 0.6 \\
\hline
\end{tabular}

Source: The data for contracts before 1990 come from Ocampo (1987).

Sena Contributions were increased to $2 \%$ in 1982 from $1 \%$ until then. ICBF contributions were increased to $3 \%$ in 1989 from $2 \%$ untile then.

Increases in health contributions have been gradual (7\% until 1994, 8\% in 1995 and $12 \%$ afterwards). Contributions for pensions increased from $4.5 \%$ to $6.5 \%$ in 1985 , to $8 \%$ in 1992 , to $11.5 \%$ in 1994 , to $12,5 \%$ in 1995 . Since 1996 the contributions for workers earning more than 4 minimum wages is $14.5 \%$ and for workers earning less than 4 minimum wages is $13.5 \%$. 


\section{DESCRIPTIVE STATISTICS BY SECTOR}

\begin{tabular}{|c|c|c|c|c|c|c|c|c|c|c|}
\hline \multirow[t]{2}{*}{ Sector } & \multicolumn{2}{|c|}{$\begin{array}{l}\text { Share in total } \\
\text { employment }\end{array}$} & \multicolumn{2}{|c|}{\begin{tabular}{|}
$\begin{array}{c}\text { Share of wage-earners } \\
\text { in total employment }\end{array}$
\end{tabular}} & \multicolumn{2}{|c|}{$\begin{array}{c}\text { Share of skilled workers } \\
\text { in total employment }\end{array}$} & \multicolumn{2}{|c|}{$\begin{array}{c}\text { Skilled / Unskilled } \\
\text { employment }\end{array}$} & \multicolumn{2}{|c|}{$\begin{array}{l}\text { Skilled workers' wages / } \\
\text { Unskilled workers' wages }\end{array}$} \\
\hline & $1976-1991$ & $1992-1996$ & $1976-1991$ & $1992-1996$ & $1976-1991$ & $1992-1996$ & $1976-1991$ & $1992-1996$ & $1976-1991$ & $1992-1996$ \\
\hline Manufacturing & 29.75 & 27.57 & 76.10 & 76.53 & 10.45 & 13.96 & 0.118 & 0.162 & 3.095 & 2.937 \\
\hline Electricity and gas & 1.08 & 0.97 & 98.90 & 98.81 & 23.87 & 33.62 & 0.329 & 0.514 & 2.330 & 2.282 \\
\hline Construction & 6.46 & 6.31 & 64.21 & 58.84 & 9.46 & 12.45 & 0.106 & 0.143 & 3.493 & 3.375 \\
\hline $\begin{array}{l}\text { Retail, restaurants and } \\
\text { hotels }\end{array}$ & 19.65 & 21.15 & 50.35 & 52.80 & 10.96 & 15.81 & 0.126 & 0.188 & 2.621 & 2.431 \\
\hline $\begin{array}{l}\text { Transportation and } \\
\text { Communications }\end{array}$ & 7.12 & 7.03 & 70.03 & 68.12 & 11.09 & 14.69 & 0.127 & 0.173 & 2.333 & 2.321 \\
\hline Financial services & 8.48 & 9.47 & 77.36 & 79.23 & 30.10 & 37.95 & 0.443 & 0.615 & 2.238 & 2.487 \\
\hline $\begin{array}{l}\text { Personal and Gubernamental } \\
\text { services }\end{array}$ & 25.83 & 25.73 & 56.14 & 59.41 & 30.17 & 38.27 & 0.441 & 0.622 & 2.432 & 2.376 \\
\hline Total urban & 98.36 & 98.23 & 62.66 & 64.06 & 17.63 & 23.28 & 0.218 & 0.304 & 2.658 & 2.626 \\
\hline
\end{tabular}

Source: NHS 
Table 3

Annual Average Growth in Total Real Labor Cost (\%)

\begin{tabular}{|l|c|c|c|c|}
\hline \multicolumn{1}{|c|}{ Sector } & \multicolumn{4}{|c|}{ Unskilled Employment (less than 12 years of education) } \\
\hline & $1977-1985$ & $\mathbf{1 9 8 6 - 1 9 9 1}$ & $\mathbf{1 9 9 2 - 1 9 9 6}$ & $\mathbf{1 9 7 7 - 1 9 9 6}$ \\
\hline Manufacturing & 1.80 & -1.45 & 8.09 & 2.40 \\
Electricity and gas & 3.03 & -1.16 & 9.89 & 3.45 \\
Construction & 2.03 & -1.08 & 8.08 & 3.49 \\
$\begin{array}{l}\text { Retail, restaurants and } \\
\text { hotels }\end{array}$ & 2.23 & -0.97 & 8.28 & 2.61 \\
$\begin{array}{l}\text { Transportation and } \\
\text { Communications }\end{array}$ & 1.11 & -1.84 & 7.49 & 2.78 \\
Financial services & 1.58 & -1.38 & 8.85 & 2.82 \\
$\begin{array}{l}\text { Personal and Gubernamental } \\
\text { services }\end{array}$ & & & & \\
\hline Total urban & 1.65 & -1.34 & 8.36 & 2.43 \\
\hline
\end{tabular}

\begin{tabular}{|l|c|c|c|c|}
\hline \multicolumn{1}{|c|}{ Sector } & \multicolumn{4}{|c|}{ Skilled Employment (12 years of education or more) } \\
\hline & $\mathbf{1 9 7 7 - 1 9 8 5}$ & $\mathbf{1 9 8 6 - 1 9 9 1}$ & $\mathbf{1 9 9 2 - 1 9 9 6}$ & $\mathbf{1 9 7 7 - 1 9 9 6}$ \\
\hline Manufacturing & -1.96 & -2.78 & 11.85 & 1.25 \\
Electricity and gas & 3.58 & -2.34 & 15.58 & 4.81 \\
Construction & -0.32 & 0.55 & 13.41 & 3.37 \\
$\begin{array}{l}\text { Retail, restaurants and } \\
\text { hotels }\end{array}$ & -1.68 & -0.59 & 10.04 & 1.58 \\
$\begin{array}{l}\text { Transportation and } \\
\text { Communications }\end{array}$ & 0.73 & -0.11 & 10.79 & 3.00 \\
Financial services & -1.38 & -0.56 & 12.83 & 2.42 \\
$\begin{array}{l}\text { Personal and Gubernamental } \\
\text { services }\end{array}$ & -1.14 & -1.61 & 11.81 & 1.95 \\
\hline Total urban & -1.63 & -1.71 & 11.36 & 1.59 \\
\hline
\end{tabular}


Table 4

Mincer Income Equation

\begin{tabular}{|c|c|c|c|}
\hline & 1988 & Ty92 & T996 \\
\hline Log (Wages) & & & \\
\hline Constant & $\begin{array}{l}10.0354 \\
(576.90)\end{array}$ & $\begin{array}{l}11.2707 \\
(624.09)\end{array}$ & $\begin{array}{l}12.0258 \\
(670.16)\end{array}$ \\
\hline Education & $\begin{array}{r}0.044 \\
(52.01)\end{array}$ & $\begin{array}{l}0.0182 \\
(30.54)\end{array}$ & $\begin{array}{l}0.0181 \\
(31.91)\end{array}$ \\
\hline Gender & $\begin{array}{l}0.1671 \\
(23.45)\end{array}$ & $\begin{array}{l}0.1688 \\
(22.11)\end{array}$ & $\begin{array}{l}0.1585 \\
(20.18)\end{array}$ \\
\hline Experience & $\begin{array}{r}0.019 \\
(24.37)\end{array}$ & $\begin{array}{l}0.0185 \\
(21.57)\end{array}$ & $\begin{array}{l}0.0172 \\
(20.36)\end{array}$ \\
\hline Experience ${ }^{2}$ & $\begin{array}{l}-0.0002 \\
(-20.53)\end{array}$ & $\begin{array}{l}-0.0003 \\
(-21.43)\end{array}$ & $\begin{array}{l}-0.0002 \\
(-18.80)\end{array}$ \\
\hline $\begin{array}{l}\text { Dummy health } \\
\text { coverage }\end{array}$ & $\begin{array}{r}0.0628 \\
(6.84)\end{array}$ & $\begin{array}{l}0.1421 \\
(13.93)\end{array}$ & $\begin{array}{l}0.1838 \\
(18.63)\end{array}$ \\
\hline $\begin{array}{l}\text { Health coverage* } \\
\text { minimum wage }\end{array}$ & $\begin{array}{l}0.2848 \\
(20.48)\end{array}$ & $\begin{array}{l}0.2342 \\
(15.52)\end{array}$ & $\begin{array}{r}0.1320 \\
(8.31)\end{array}$ \\
\hline Minimum wage & $\begin{array}{r}-1.0045 \\
(-107.65)\end{array}$ & $\begin{array}{r}-1.1018 \\
(-106.29)\end{array}$ & $\begin{array}{l}-1.0907 \\
(-99.55)\end{array}$ \\
\hline Agriculture & $\begin{array}{r}0.1267 \\
(5.08)\end{array}$ & $\begin{array}{r}0.1114 \\
(3.73)\end{array}$ & $\begin{array}{r}0.4358 \\
(1.28)\end{array}$ \\
\hline Mining & $\begin{array}{r}0.1865 \\
(4.13)\end{array}$ & $\begin{array}{r}0.4505 \\
(3.73)\end{array}$ & $\begin{array}{r}0.2378 \\
(3.90)\end{array}$ \\
\hline Electricity & $\begin{array}{r}0.0547 \\
(1.45)\end{array}$ & $\begin{array}{r}0.0398 \\
(0.92)\end{array}$ & $\begin{array}{r}0.1868 \\
(4.32)\end{array}$ \\
\hline Construction & $\begin{array}{r}0.0874 \\
(5.73)\end{array}$ & $\begin{array}{r}0.0602 \\
(3.64)\end{array}$ & $\begin{array}{r}0.0733 \\
(4.48)\end{array}$ \\
\hline Retail & $\begin{array}{r}-0.0095 \\
(-1.02)\end{array}$ & $\begin{array}{r}0.0367 \\
(3.61)\end{array}$ & $\begin{array}{r}0.0449 \\
(4.20)\end{array}$ \\
\hline Communications & $\begin{array}{r}0.0463 \\
(3.14)\end{array}$ & $\begin{array}{r}0.0751 \\
(4.65)\end{array}$ & $\begin{array}{r}0.0742 \\
(4.66)\end{array}$ \\
\hline Financial Serv. & $\begin{array}{r}0.0951 \\
(6.28)\end{array}$ & $\begin{array}{r}0.1564 \\
(9.78)\end{array}$ & $\begin{array}{r}0.1545 \\
(9.85)\end{array}$ \\
\hline Government Serv & $\begin{array}{r}-0.0003 \\
(-0.00)\end{array}$ & $\begin{array}{r}-0.0009 \\
(-0.09)\end{array}$ & $\begin{array}{r}0.0413 \\
(3.97)\end{array}$ \\
\hline Other Services & $\begin{array}{r}-0.1665 \\
(-0.43)\end{array}$ & $\begin{array}{r}0.1180 \\
(0.70)\end{array}$ & $\begin{array}{r}0.4188 \\
(2.38)\end{array}$ \\
\hline Barranquilla & $\begin{array}{r}-0.0083 \\
(-0.77)\end{array}$ & $\begin{array}{r}0.0193 \\
(1.72)\end{array}$ & $\begin{array}{r}0.0374 \\
(3.17)\end{array}$ \\
\hline Bucaramanga & $\begin{array}{r}0.0065 \\
(0.55)\end{array}$ & $\begin{array}{r}-0.0504 \\
(-4.05)\end{array}$ & $\begin{array}{r}-0.0662 \\
(-5.23)\end{array}$ \\
\hline Manizales & $\begin{array}{r}0.0264 \\
(1.59)\end{array}$ & $\begin{array}{r}-0.0646 \\
(-3.67)\end{array}$ & $\begin{array}{r}-0.1159 \\
(-6.77)\end{array}$ \\
\hline Medellin & $\begin{array}{r}0.0594 \\
(6.63)\end{array}$ & $\begin{array}{r}-0.0256 \\
(-2.50)\end{array}$ & $\begin{array}{r}-0.0018 \\
(-0.18)\end{array}$ \\
\hline Cali & $\begin{array}{r}0.0508 \\
(4.77)\end{array}$ & $\begin{array}{r}0.0250 \\
(2.15)\end{array}$ & $\begin{array}{r}0.0189 \\
(1.52)\end{array}$ \\
\hline Pasto & $\begin{array}{r}-0.1405 \\
(-9.22)\end{array}$ & $\begin{array}{l}-0.1943 \\
(-12.38)\end{array}$ & $\begin{array}{r}-0.0781 \\
(-4.87)\end{array}$ \\
\hline $\begin{array}{l}\text { No. observations } \\
\text { R2 }\end{array}$ & $\begin{array}{l}29476 \\
0.5504\end{array}$ & $\begin{array}{r}26900 \\
0.5526\end{array}$ & $\begin{array}{l}25887 \\
0.5269\end{array}$ \\
\hline
\end{tabular}


Table 5

FACTOR DEMANDS: GL Specification

MANUFACTURING SECTOR

1977:1-1996:4

\begin{tabular}{|c|c|c|c|c|c|c|c|}
\hline & Constant & & $\begin{array}{c}\text { Relative } \\
\text { prices }\end{array}$ & & Production & $\mathbf{R}^{2}$ & D.W. \\
\hline Skilled employment & $\begin{array}{c}-0.7736 \\
(-3.06)\end{array}$ & *** & $\begin{array}{c}0.7984 \\
(2.72)\end{array}$ & $\star \star \star *$ & $\begin{array}{l}1.0133 \\
(6.38)\end{array}$ & 0.79 & 2.04 \\
\hline Unskilled employment & $\begin{array}{c}1.2058 \\
(8.66)\end{array}$ & $* * *$ & $\begin{array}{c}-0.2495 \\
(-2.24)\end{array}$ & $* * *$ & $\begin{array}{c}0.0670 \\
(1.15)\end{array}$ & 0.23 & 1.94 \\
\hline
\end{tabular}

\begin{tabular}{lcccc}
\hline \multicolumn{5}{c}{ PRICE, INCOME AND SUBSTITUTION ELASTICITIES } \\
\hline Own-wage elasticities & $\mathbf{1 9 7 6 - 1 9 8 1}$ & $\mathbf{1 9 8 2 - 1 9 8 5}$ & $\mathbf{1 9 8 6 - 1 9 9 1}$ & $\mathbf{1 9 9 2 - 1 9 9 6}$ \\
\hline$\eta_{\mathrm{ee}}$ & -0.593 & -0.523 & -0.431 & -0.350 \\
$\eta_{\mathrm{oo}}$ & -0.487 & -0.409 & -0.390 & -0.400 \\
Elasticity of substitution & & & & \\
$\sigma_{\mathrm{eo}}$ & 3.850 & 2.876 & 2.498 & 1.979 \\
Output elasticities & & & & \\
$\varepsilon_{\mathrm{ey}}$ & 2.204 & 2.008 & 1.986 & 1.968 \\
$\varepsilon_{\mathrm{oy}}$ & 1.050 & 1.049 & 1.060 & 1.068 \\
\hline
\end{tabular}

o-unskilled employment, $e$-skilled employment, $y$-production

Employment in number of hours. 
Table 7

DYNAMIC LABOR DEMAND ESTIMATIONS

1977:02 - 1996:04

\begin{tabular}{|c|c|c|c|c|c|c|c|}
\hline & $\begin{array}{c}\text { Total E } \\
(1)\end{array}$ & $\begin{array}{c}\text { Total E } \\
(2)\end{array}$ & $\begin{array}{c}\text { Total E } \\
(3)\end{array}$ & $\begin{array}{c}\text { Skilled E } \\
(4)\end{array}$ & $\begin{array}{c}\text { Unskilled E } \\
(5)\end{array}$ & $\begin{array}{c}\text { Skilled E } \\
(6)\end{array}$ & $\begin{array}{c}\text { Unskilled E } \\
(7)\end{array}$ \\
\hline Constant & $\begin{array}{r}0.0156 \\
(0.44)\end{array}$ & $\begin{array}{r}0.0156 \\
(0.44)\end{array}$ & $\begin{array}{r}0.0156 \\
(0.44)\end{array}$ & $\begin{array}{r}-0.0364 \\
(-0.36)\end{array}$ & $\begin{array}{l}0.2143 \\
(4.18)\end{array}$ & $\begin{array}{l}-0.1005 \\
(-1.96)\end{array}$ & $\begin{array}{l}0.2143 \\
(4.18)\end{array}$ \\
\hline Production $_{\mathrm{t}}$ & $\begin{array}{l}0.5666 \\
(2.84)^{* * *}\end{array}$ & $\begin{array}{l}0.5666 \\
(2.84) * * *\end{array}$ & $\begin{array}{l}0.5666 \\
(2.84) * * *\end{array}$ & $\begin{array}{l}1.0237 \\
(4.17)^{* * *}\end{array}$ & $\begin{array}{l}0.6041 \\
(2.95) * * *\end{array}$ & $\begin{array}{l}1.0250 \\
(4.17)\end{array}$ & $\begin{array}{l}0.6041 \\
(2.95)\end{array}$ \\
\hline Production ${ }_{\mathrm{t}-1}$ & $\begin{array}{r}-0.0342 \\
(-0.17)\end{array}$ & $\begin{array}{r}-0.0342 \\
(-0.17)\end{array}$ & $\begin{array}{r}-0.0342 \\
(-0.17)\end{array}$ & $\begin{array}{r}-0.1125 \\
(-0.44)\end{array}$ & $\begin{array}{r}0.0365 \\
(0.18)\end{array}$ & $\begin{array}{r}-0.1123 \\
(-0.43)\end{array}$ & $\begin{array}{r}0.0365 \\
(0.18)\end{array}$ \\
\hline Own Wages $_{t}$ & $\begin{array}{r}0.0175 \\
(0.18)\end{array}$ & $\begin{array}{r}0.0175 \\
(0.18)\end{array}$ & $\begin{array}{r}0.0175 \\
(0.18)\end{array}$ & $\begin{array}{r}0.0877 \\
(0.74)\end{array}$ & $\begin{array}{r}0.1224 \\
(1.22)\end{array}$ & $\begin{array}{r}0.0880 \\
(0.74)\end{array}$ & $\begin{array}{r}0.1224 \\
(1.22)\end{array}$ \\
\hline Own Wages ${ }_{t-1}$ & $\begin{array}{l}-0.1636 \\
(-1.70)\end{array}$ & $\begin{array}{c}-0.1636 \\
(-1.70)\end{array}$ & $\begin{array}{c}-0.1636 \\
(-1.70)\end{array}$ & $\begin{array}{c}-0.2237 \\
(-1.81)\end{array}$ & $\begin{array}{r}-0.0385 \\
(-0.38)\end{array}$ & $\begin{array}{c}-0.2254 \\
(-1.81)\end{array}$ & $\begin{array}{r}-0.0385 \\
(-0.38)\end{array}$ \\
\hline Other type of E Wages ${ }_{t}$ & & & & $\begin{array}{r}0.1215 \\
(0.98)\end{array}$ & $\begin{array}{r}0.1222 \\
(1.24)\end{array}$ & $\begin{array}{r}0.1211 \\
(0.98)\end{array}$ & $\begin{array}{r}0.1222 \\
(1.24)\end{array}$ \\
\hline Other type of E Wages ${ }_{t-1}$ & & & & $\begin{array}{l}-0.2538 \\
(-2.05)\end{array}$ & $\begin{array}{l}-0.3684 \\
(-3.70)\end{array}$ & $\begin{array}{l}-0.2563 \\
(-2.07)\end{array}$ & $\begin{array}{l}-0.3684 \\
(-3.70)\end{array}$ \\
\hline $\mathrm{R} 1_{\mathrm{t}}{ }^{*} \mathrm{E}_{\mathrm{t}-1}$ & $\begin{array}{r}0.0334 \\
(0.73)\end{array}$ & & & $\begin{array}{r}-0.0680 \\
(-0.92)\end{array}$ & $\begin{array}{r}0.0089 \\
(0.17)\end{array}$ & & \\
\hline$R 2{ }_{t}^{*} E_{t-1}$ & & $\begin{array}{r}-0.0364 \\
(-0.73)\end{array}$ & & & & $\begin{array}{r}0.0607 \\
(0.82)\end{array}$ & $\begin{array}{r}-0.0097 \\
(-0.17)\end{array}$ \\
\hline Dum91* $\mathrm{E}_{\mathrm{t}-1}$ & & & $\begin{array}{r}-0.0104 \\
(-0.73)\end{array}$ & & & & \\
\hline$E_{t-1}$ & $\begin{array}{l}0.5760 \\
(4.95)^{* * *}\end{array}$ & $\begin{array}{l}0.6459 \\
(5.39)\end{array}$ & $\begin{array}{l}0.6095 \\
(5.64) * * \star\end{array}$ & $\begin{array}{l}0.4679 \\
(4.11)^{\star * *}\end{array}$ & $\begin{array}{l}0.3025 \\
(2.52)\end{array}$ & $\begin{array}{l}0.4070 \\
(2.43)\end{array}$ & $\begin{array}{c}0.3211 \\
(2.46)\end{array}$ \\
\hline $\begin{array}{l}\text { R2 } \\
\text { DW }\end{array}$ & $\begin{array}{r}0.9790 \\
2.63\end{array}$ & $\begin{array}{r}0.9790 \\
2.63\end{array}$ & $\begin{array}{r}0.9790 \\
2.63\end{array}$ & $\begin{array}{r}0.9847 \\
1.96\end{array}$ & $\begin{array}{r}0.9699 \\
2.42\end{array}$ & $\begin{array}{r}0.9847 \\
1.98\end{array}$ & $\begin{array}{r}0.9699 \\
2.42\end{array}$ \\
\hline
\end{tabular}

Number of observations: 75

R1: Severance Payments

R2: Dismissal Costs

Source: NHS 
Table 8

Labor demand estimation results Firm level

\begin{tabular}{|c|c|c|c|c|c|}
\hline & \multicolumn{3}{|c|}{ Basic Model } & \multicolumn{2}{|c|}{ Cycle } \\
\hline & [1] & [2] & [3] & [3] & [3] \\
\hline & OLS & IV & OLS + Di & IV & $\mathrm{IV}+\mathrm{Di}$ \\
\hline \multirow[t]{2}{*}{ Employment (t-1) } & 0.964 & 0.978 & 0.965 & 0.987 & 0.988 \\
\hline & $(526.20)$ & $(492.76)$ & $(476.46)$ & (349.27) & $(331), .77)$ \\
\hline \multirow[t]{2}{*}{ Labor cost } & -0.050 & -0.051 & -0.062 & -0.054 & -0.070 \\
\hline & $(-18.19)$ & $(-17.76)$ & $(-19.08)$ & $(-17.86)$ & $(-20.13)$ \\
\hline \multirow[t]{2}{*}{ Price of materials } & 0.024 & 0.030 & 0.047 & 0.024 & 0.051 \\
\hline & (3.78) & $(4.27)$ & (5.15) & (2.43) & (3.83) \\
\hline \multirow[t]{2}{*}{ Capital Stock } & 0.025 & 0.018 & 0.027 & 0.015 & 0.018 \\
\hline & $(20.99)$ & $(14.38)$ & $(19.49)$ & (8.60) & (9.19) \\
\hline \multirow[t]{2}{*}{ Growth in production } & 0.245 & 0.243 & 0.242 & 0.262 & 0.263 \\
\hline & $(58.45)$ & $(56.22)$ & $(56.18)$ & $(40.88)$ & $(41.02)$ \\
\hline \multirow[t]{2}{*}{ Year } & -0.001 & 0.000 & & 0.001 & 0.001 \\
\hline & $(-2.24)$ & $(1.19)$ & & $(1.91)$ & $(2.06)$ \\
\hline \multirow[t]{2}{*}{ Employment (t-1) } & & & & -0.022 & -0.022 \\
\hline & & & & $(-5.51)$ & $(-5.66)$ \\
\hline \multirow[t]{2}{*}{ Labor cost } & & & & 0.003 & 0.003 \\
\hline & & & & (2.06) & (1.99) \\
\hline \multirow[t]{2}{*}{ Price of materials } & & & & 0.013 & 0.011 \\
\hline & & & & (0.99) & $(0.85)$ \\
\hline \multirow[t]{2}{*}{ Capital Stock } & & & & 0.009 & 0.009 \\
\hline & & & & (3.29) & (3.44) \\
\hline \multirow[t]{2}{*}{ Growth in production } & & & & -0.063 & -0.065 \\
\hline & & & & $(-6.84)$ & $(-7.05)$ \\
\hline Adj. R2 & 0.965 & 0.966 & 0.966 & 0.966 & 0.966 \\
\hline
\end{tabular}


Table 9

Labor Demand Estimations

Panel of Manufacturing Sectors

1978-1995

\begin{tabular}{|c|c|c|c|c|c|c|}
\hline & \multicolumn{3}{|c|}{ Basic Equation } & \multicolumn{3}{|c|}{ Structural Change } \\
\hline & $\begin{array}{l}\text { OLS } \\
(1)\end{array}$ & $\begin{array}{l}\text { Fixed Eff. } \\
(2)\end{array}$ & $\begin{array}{l}\text { IV } \\
(3)\end{array}$ & $\begin{array}{l}\text { OLS } \\
(4)\end{array}$ & $\begin{array}{l}\text { Fixed Eff. } \\
(5)\end{array}$ & $\begin{array}{l}\text { IV } \\
(6)\end{array}$ \\
\hline Employment (t-1) & $\begin{array}{l}0.7476 \\
(52.31)^{* * *}\end{array}$ & $\begin{array}{l}0.4417 \\
(21.48) \text { *** }\end{array}$ & $\begin{array}{l}0.5767 \\
(6.00))^{* * *}\end{array}$ & $\begin{array}{l}0.7791 \\
(62.47) * * *\end{array}$ & $\begin{array}{l}0.5165 \\
(28.36)\end{array}$ & $\begin{array}{l}0.6119 \\
(7.48)\end{array}$ \\
\hline Total wage & $\begin{array}{l}-0.2903 \\
(-11.57)\end{array}$ & $\begin{array}{l}-0.1413 \\
(-3.57)\end{array}$ & $\begin{array}{l}-0.6056 \\
(-4.04)\end{array}$ & $\begin{array}{l}-0.2432 \\
(-11.84)\end{array}$ *** & $\begin{array}{l}-0.2029 \\
(-6.02)\end{array}$ & $\begin{array}{l}-0.4746 \\
(-4.38)\end{array}$ \\
\hline Input prices & $\begin{array}{l}-0.2208 \\
(-5.59)\end{array}$ & $\begin{array}{l}-0.3755 \\
(-7.81)^{* * *}\end{array}$ & $\begin{array}{r}-0.5197 \\
(-3.90)\end{array}$ & $\begin{array}{l}-0.3068 \\
(-6.84)^{* * *}\end{array}$ & $\begin{array}{r}-0.4986 \\
(-9.68)\end{array}$ & $\begin{array}{l}-0.777 \\
(-3.69)\end{array}$ \\
\hline Capital stock & $\begin{array}{l}0.0289 \\
(2.85)\end{array}$ & $\begin{array}{r}0.0212 \\
(0.69)\end{array}$ & $\begin{array}{r}-0.0198 \\
(-1.58)\end{array}$ & $\begin{array}{l}0.0351 \\
(4.52)\end{array}$ & $\begin{array}{l}0.0595 \\
(2.55)\end{array}$ & $\begin{array}{r}0.0118 \\
(0.93)\end{array}$ \\
\hline Value Added & $\begin{array}{l}0.2154 \\
(18.94) * * *\end{array}$ & $\begin{array}{l}0.2953 \\
(22.12) \text { *** }\end{array}$ & $\begin{array}{l}0.4465 \\
(4.52)\end{array}$ & $\begin{array}{l}0.1777 \\
(17.77)^{* * *}\end{array}$ & $\begin{array}{l}0.2593 \\
(21.45) \text { *** }\end{array}$ & $\begin{array}{l}0.3683 \\
(4.71)\end{array}$ \\
\hline Year & $\begin{array}{r}-0.0007 \\
(-0.48)\end{array}$ & $\begin{array}{r}-0.0021 \\
(-1.25)\end{array}$ & $\begin{array}{r}0.0001 \\
(0.07)\end{array}$ & & & \\
\hline $\mathrm{D}^{\star}$ Employment $(\mathrm{t}-1)$ & & & & $\begin{array}{l}-0.8045 \\
(-26.50)\end{array}$ & $\begin{array}{l}-0.6102 \\
(-20.28)\end{array}$ & $\begin{array}{l}-0.5939 \\
(-5.77)\end{array}$ \\
\hline D*Total wage & & & & $\begin{array}{r}0.1721 \\
(5.29) * * *\end{array}$ & $\begin{array}{c}0.1424 \\
(4.37)\end{array}$ & $\begin{array}{r}0.4223 \\
(1.75) \text { * }\end{array}$ \\
\hline$D^{*}$ Input prices & & & & $\begin{array}{l}0.3620 \\
(5.97)\end{array}$ & $\begin{array}{r}0.4321 \\
(7.12)\end{array}$ & $\begin{array}{l}0.9379 \\
(3.24)\end{array}$ \\
\hline$D^{*}$ Capital stock & & & & $\begin{array}{l}0.9964 \\
(29.64)\end{array}$ & $\begin{array}{l}0.7764 \\
(22.33) \text { *** }\end{array}$ & $\begin{array}{l}1.0687 \\
(5.73) \text { *** }\end{array}$ \\
\hline D*Value Added & & & & $\begin{array}{l}-0.1720 \\
(-7.64)\end{array}$ & $\begin{array}{r}-0.1513 \\
(-6.60)\end{array}$ & $\begin{array}{c}-0.4244 \\
(-1.94)\end{array}$ \\
\hline $\mathrm{R} 2$ & 0.9705 & 0.9763 & 0.9622 & 0.9825 & 0.9833 & 0.9778 \\
\hline
\end{tabular}

Total number of observations: 1502

$D$ is a dummy variable for the period 1992-1995 
Table 10

\section{Labor Demand Elasticities}

Summary of Results

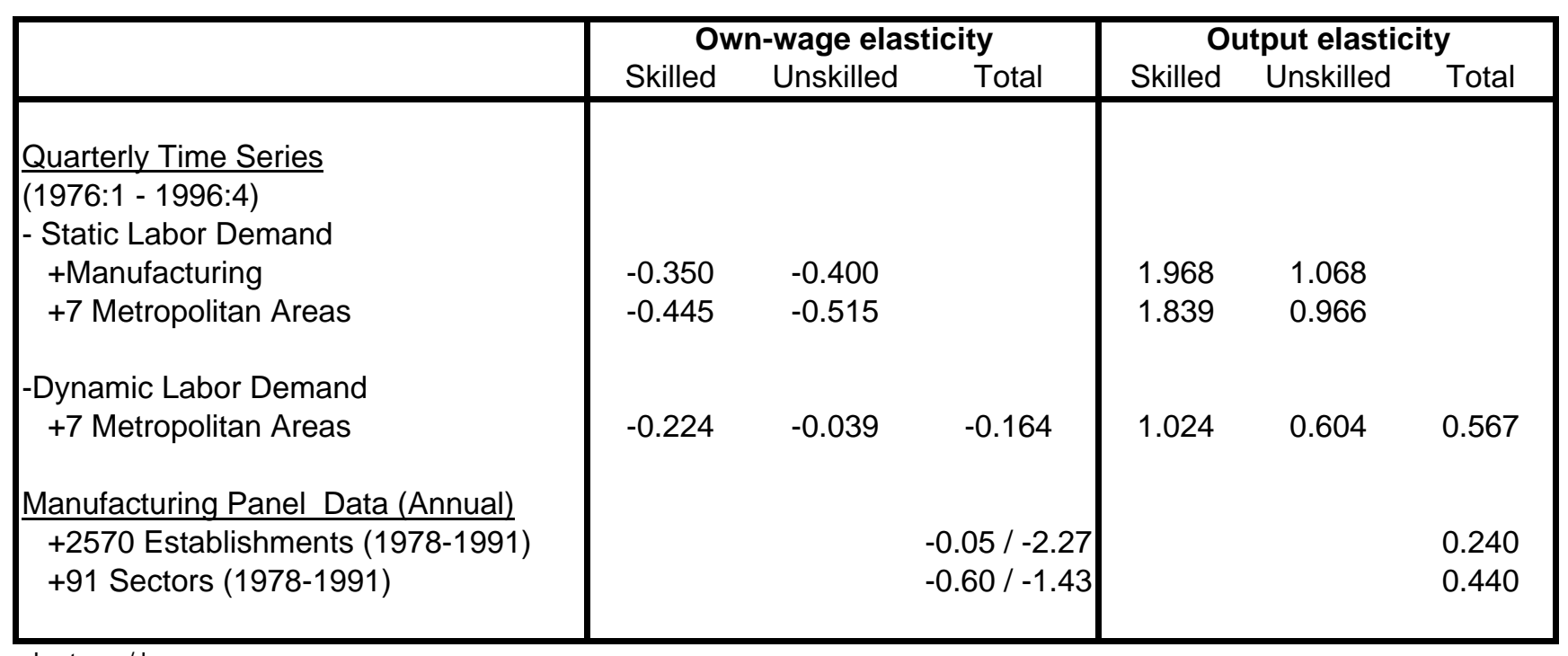

short run / long run 